\title{
CHEMICAL, CLINICAL, AND IMMUNOLOGICAL STUDIES ON THE \\ PRODUCTS OF HUMAN PLASMA FRACTIONATION. XXXI. THE USE OF SALT-POOR CONCENTRATED HUMAN SERUM ALBUMIN SOLUTION IN THE TREAT- MENT OF HEPATIC CIRRHOSIS 1, 2
}

\author{
By G. W. THORN, S. H. ARMSTRONG, JR., ${ }^{3}$ AND V. D. DAVENPORT \\ (From the Departments of Medicine and Physical Chemistry, Harvard Medical School, and \\ the Medical Clinic, Peter Bent Brigham Hospital, Boston)
}

(Received for publication August 22, 1945)

The response of the hypoalbuminemia of hepatic cirrhosis to high-protein, high-vitamin therapy with establishment of positive nitrogen balance is correlated both with the severity and the prognosis of the disease ( 1 to 7 ). Because hypoalbuminemia once established plays an important rôle in augmenting disability by favoring generalized edema and possibly further impairment of organ function, ( 8 to 11 ) in severe cirrhosis there have been several attempts to supplement dietary with parenteral proteins, using whole blood, plasma, and concentrated ascitic fluid (12). Expected limiting factors in the response of both hypoalbuminemia and edema to such parenteral fluids are their relatively low albumin and high sodium content. Recently the use of concentrated human serum albumin, approximately 0.3 molar with respect to sodium, has been reported (13).

The present study extends these observations using, however, a preparation of human serum albumin extremely low in sodium content. Both the chemical characteristics of this preparation and the response of edema, plasma protein levels, and nitrogen balance of certain stages of chronic Bright's disease to its administration have been described in previous papers $(14,15)$. Here, in a small group of patients with varying types of hepatic cirrhosis, we have attempted to answer the following questions:

\footnotetext{
1 This work has been carried out in part under contract, recommended by the Committee on Medical Research, between the Office of Scientific Research and Development and Harvard University.

2 This is paper No. 42 in the series, "Studies on Plasma Proteins," from Harvard Medical School, Boston, Massachusetts, on products developed by the Department of Physical Chemistry from blood collected by the American Réd Cross.

3 Welch Fellow in Internal Medicine of the National Research Council.
}

(1) Is salt-poor concentrated human serum albumin administered intravenously an effective diuretic agent in such patients?

(2) Is there any difference in the response of generalized edema and ascitic fluid to such therapy?

(3) What effect does the administration of this preparation have on serum protein levels of patients with hepatic cirrhosis?

(4) What effect does the administration of this preparation have on nitrogen balance in the presence of adequate dietary protein?

(5) Is there any difference between the effect of protein administered by mouth and the same preparation administered intravenously?

Unfortunately, limitation of materials made direct comparison of salt-poor and standard saltcontaining albumin impossible.

\section{METHODS}

Methods of chemical and electrophoretic analyses are identical with those detailed in the previous paper (15).

In our previous study, the observation of other authors $(16,17)$ that electrophoretic analyses, uncorrected for refractive index differences between components (18), yield albumin-globulin ratios consistently lower than those obtained by the Howe method (19) was confirmed and extended in the instance of the hypoalbuminemic serum proteins of chronic Bright's disease, though both methods as a rule gave agreement in direction and approximate magnitude of change of albumin level following therapy.

That a discrepancy of this sort was not found in analysis of cirrhotic plasma proteins may be seen in the following chart, which presents albumin levels both low and high (before and after treatment) as measured by both techniques. For albumin levels below $\mathbf{3 . 0}$ grams per cent, values agreed within the limits of the methods. At higher levels electrophoresis tended to yield albumin values larger than those of the Howe method.

Studies on ascitic fluid yielded good agreement between the two methods except at total protein levels below 1.3 grams per cent: In this range limits of error of the Howe 


\begin{tabular}{l|c|c|c}
\hline & \multicolumn{2}{|c|}{ Albumin level (grams per cent) } & Discrepancy \\
\cline { 2 - 4 } Patient & Howe & $\begin{array}{c}\text { Uncorrected } \\
\text { electrophoresis }\end{array}$ & $\begin{array}{c}\text { Howe minus } \\
\text { electrophoresis }\end{array}$ \\
\cline { 2 - 4 } & 1.7 & 1.8 & -0.1 \\
J. H. & 1.9 & 1.9 & 0.0 \\
H. F. & 1.9 & 1.9 & 0.0 \\
C. S. & 1.9 & 2.0 & +0.2 \\
K. D. & 2.2 & 2.6 & -0.1 \\
C. S. & 2.5 & 2.8 & 0.0 \\
C. S. & 2.8 & 2.8 & 0.0 \\
H. F. & 2.8 & 2.7 & +0.1 \\
J. H. & 2.8 & 3.7 & -0.2 \\
K. D. & 3.5 & 3.8 & -0.2 \\
C. S. & 3.6 & 5.5 & -0.8 \\
K. D. & 4.7 & 5.1 & -0.3 \\
J. B. & 4.8 & 5 & \\
\hline
\end{tabular}

partition appeared to approach the magnitude of the quantities to be measured, whereas the electrophoretic schlieren diagram remained susceptible of quite accurate interpretation.

\section{Selection and regimen of patients}

Five patients, selected because of hypoalbuminemia, edema, and ascites, represented a considerable variety of hepatic cirrhoses. On clinical grounds, 2 were judged pure Laennec's cirrhosis; 1 of these had an alcoholic background. Liver biopsy in the third patient, who had been long exposed both to alcohol and other known hepatic toxins (20), disclosed the histological picture of severe toxic cirrhosis and healed acute yellow atrophy. In the fourth patient, both clinical and pathological evidence indicated an old alcoholic Laennec's cirrhosis on which a biliary cirrhosis due to common duct obstruction by stone had been superimposed. The fifth patient also gave histological evidence of severe biliary cirrhosis due to carcinoma of the intrahepatic bile ducts which had extensively invaded the liver and spread elsewhere in the peritoneal cavity. Detailed clinical summaries are recorded at the end of this paper.

Distribution of components of the initial electrophoretic schlieren diagrams of the plasma proteins of these patients is presented in Table I and illustrated together with certain clinical data in Figure 1. In addition to the hypoalbuminemia, 4 of these patients displayed the striking selective increase in gamma globulins that has been previously described in hepatic cirrhosis (21).

During these studies patients were maintained on at least 1 gram of protein per $\mathrm{kgm}$. of body weight, over 200 grams of carbohydrate, and between 30 to 70 grams of fat. A constant quantity of vitamin B complex and liver extract was given daily throughout control and treatment periods. The diet was salt-poor ( 1 to 2 grams of salt daily) in all but one experiment. Fluid intake and output were measured and the patients were weighed daily not only during experiments but for prolonged control periods before and afterwards. Intake of fluid was maintained constant. On days of albumin administration, an equivalent volume of fluid was subtracted from the patients' drinking water. Blood samples were drawn fast-
TABLE I

Distribution of components in initial electrophoretic schlieren diagrams of plasma proteins

\begin{tabular}{c|c|c|c|c|c|c}
\hline \hline Patient & $\begin{array}{c}\text { Albu- } \\
\text { mins } \\
\text { per cent }\end{array}$ & $\begin{array}{c}\alpha_{1}- \\
\text { Glob- } \\
\text { ulins } \\
\text { per cent }\end{array}$ & $\begin{array}{c}\alpha_{2} \\
\text { Glob- } \\
\text { ulins } \\
\text { per cent }\end{array}$ & $\begin{array}{c}\text { G- } \\
\text { Glob- } \\
\text { ulins } \\
\text { per cent }\end{array}$ & $\begin{array}{c}\text { Fibrin- } \\
\text { ogen } \\
\text { per cent }\end{array}$ & $\begin{array}{c}\gamma- \\
\text { Glob- } \\
\text { ulins } \\
\text { per cent }\end{array}$ \\
\hline K. D. & 29 & 6 & 9 & 15 & 15 & 26 \\
J. M. & 38 & 6 & 10 & 15 & 13 & 18 \\
C. S. & 29 & 5 & 5 & 13 & 14 & 347 \\
H. F. & 26 & 7 & 5 & 10 & $26^{*}$ & $26^{*}$ \\
J. B.† & 41 & 9 & 14 & 16 & 11 & 9 \\
\hline Normal pooled & 55 & 5 & 9 & 13 & 7 & 11 \\
human plasma & & & & & & \\
\hline
\end{tabular}

* Resolution of fibrinogen from $\gamma$-globulin incomplete.

$\dagger$ Four days following cessation of albumin therapy.

ing. In determining nitrogen balance, methods and conventions were identical with those presented in the previous study.

\section{Albumin dosage and methods of administration}

Salt-poor albumin, supplied by the Plasma Fractionation Laboratory at the Department of Physical Chemistry in the form of a 25 per cent solution without preservative, was diluted with sterile dextrose solution so that the resulting fluid contained 10 per cent albumin and 6 per cent dextrose. Unless otherwise specified, this was administered at a rate of approximately $100 \mathrm{ml}$. per hour in standard daily dosage comprising $\mathbf{5 0}$ grams of albumin.

\section{OBSERVATIONS}

\section{Diuretic effect of salt-poor concentrated human albumin administered intravenously}

a. Single infusion of 50 grams: A diuresis, limited to the 24 hours following injection, occurred in all 5 patients (Table II). The average increase in urine volume for the group was $980 \mathrm{ml}$. It is noteworthy that this diuretic effect was observed at a time when all patients had considerable edema. The greatest diuresis occurred in the 2 patients whose anasarca was most striking (K. D. and C. S.). Concomitant changes in body weight were inconstant in direction. Moreover, in those patients who lost weight, the loss did not approximate the increase in urine volume.

b. Fifty grams daily for 3 days (total 150 grams): An increase in urine volume (averaging $710 \mathrm{ml}$.) over the control period was noted in all 5 patients (Table II). Again, the most striking diuresis occurred in the patient whose anasarca was most massive (C. S., Figure 2). In C. S. alone did diuresis persist beyond the period of therapy. 


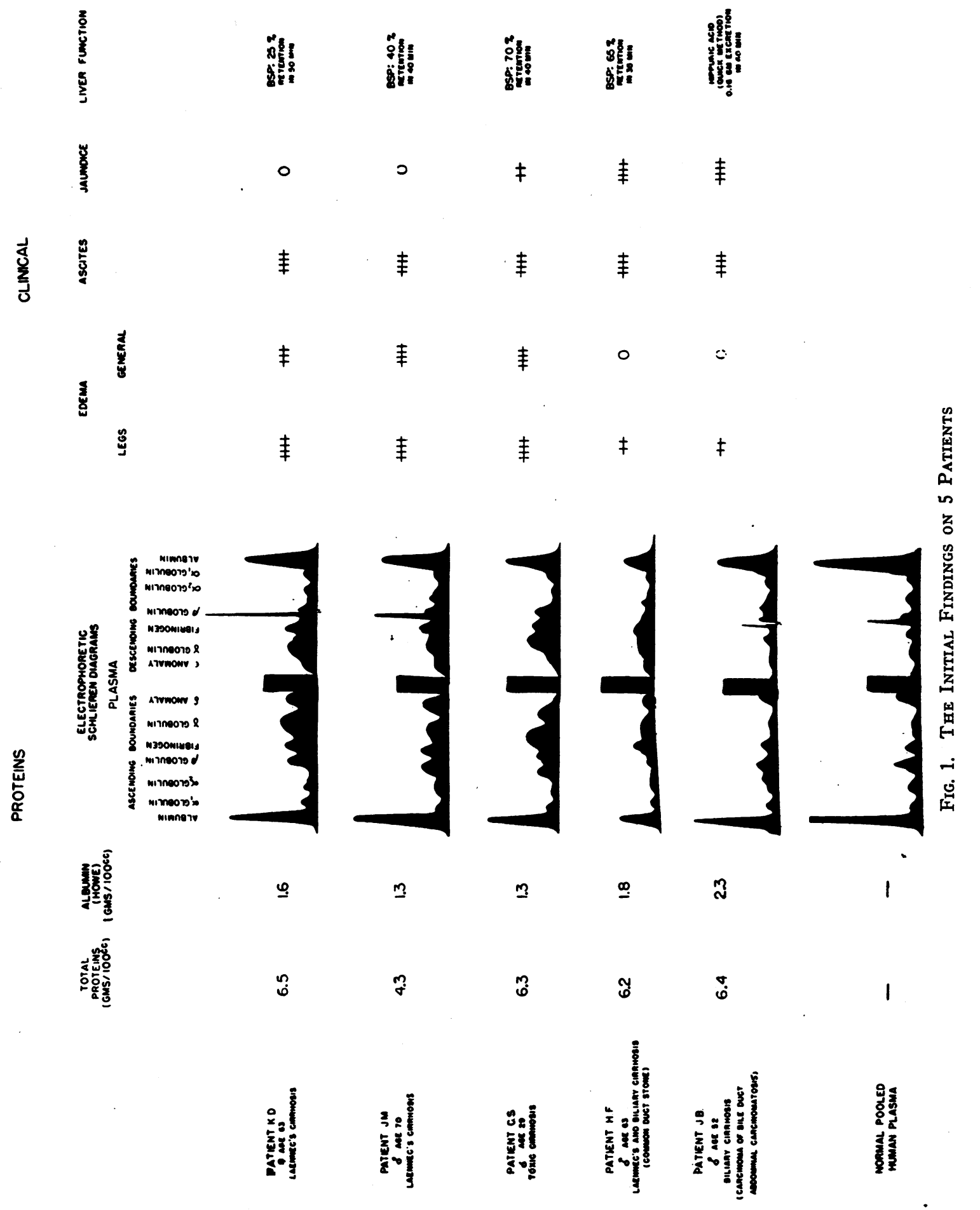




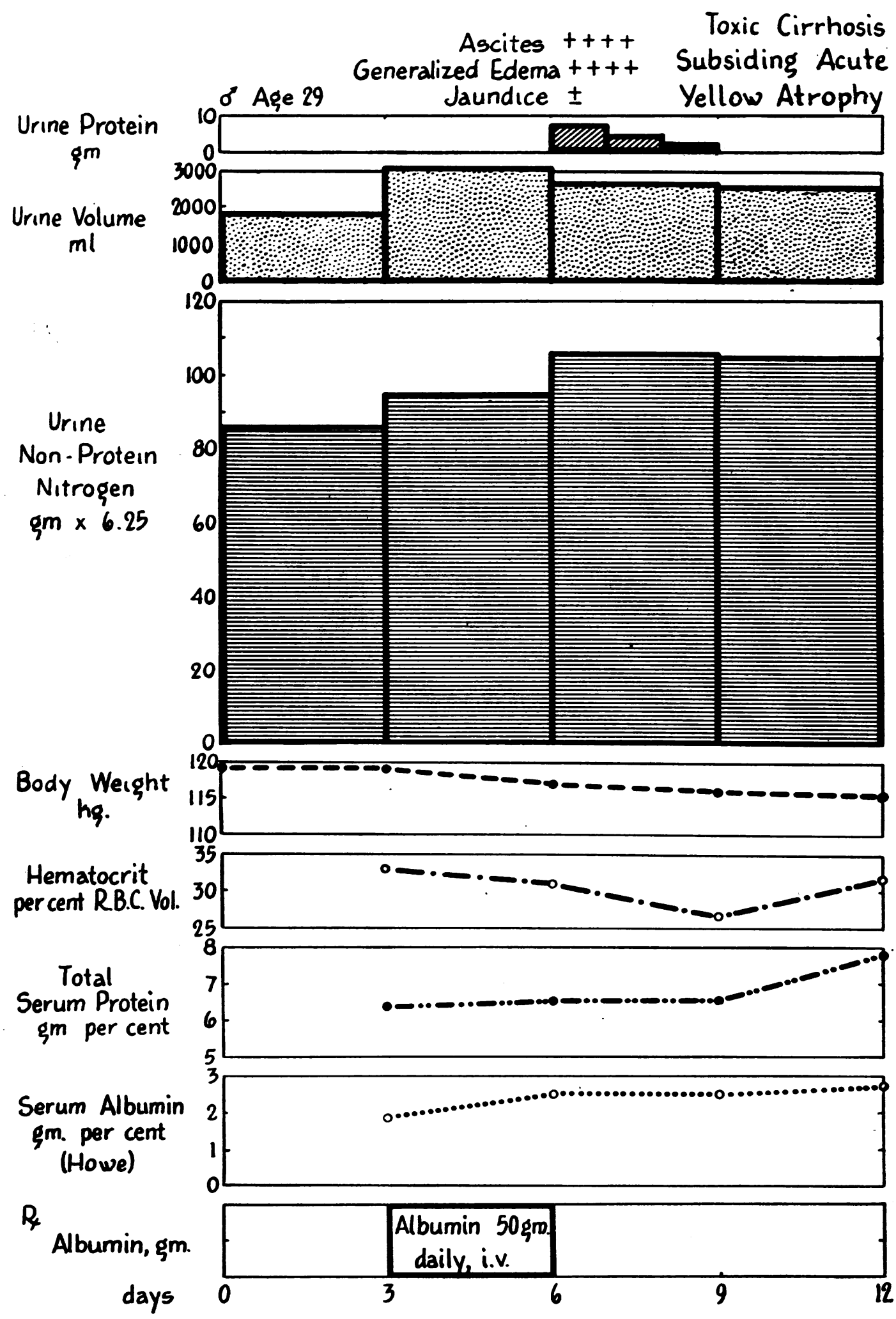

Fig. 2. (I). Albumin Therapy Patient C. S. 
TABLE II

Changes in urine volume and body weight following intravenous injection of concentrated salt-poor human albumin

\begin{tabular}{|c|c|c|c|c|c|c|}
\hline \multirow[b]{2}{*}{ Patient } & \multicolumn{3}{|c|}{$\begin{array}{l}\text { Single initial dose } \\
\text { (50 grams) }\end{array}$} & \multicolumn{3}{|c|}{$\begin{array}{l}50 \text { grams daily for } 3 \text { days } \\
\text { (150 grams total) }\end{array}$} \\
\hline & $\begin{array}{c}\text { Control } \\
\text { urine } \\
\text { volume }\end{array}$ & $\begin{array}{c}\text { Urine } \\
\text { volume } \\
\text { following } \\
\text { treat- } \\
\text { ment }\end{array}$ & $\begin{array}{c}\text { Change } \\
\text { in } \\
\text { body } \\
\text { weight }\end{array}$ & $\begin{array}{c}\text { Control } \\
\text { urine } \\
\text { volume }\end{array}$ & $\begin{array}{c}\text { Urine } \\
\text { volume } \\
\text { following } \\
\text { treat- } \\
\text { ment }\end{array}$ & $\begin{array}{c}\text { Change } \\
\text { in } \\
\text { body } \\
\text { weight }\end{array}$ \\
\hline & $\begin{array}{l}\text { ml. per } \\
24 \text { hrs. }\end{array}$ & $\begin{array}{l}\text { ml. per } \\
24 \text { hrs. }\end{array}$ & kgm. & $\begin{array}{l}\text { ml. per } \\
24 \text { hrs. }\end{array}$ & $\begin{array}{l}\text { ml. per } \\
24 \text { hrs. }\end{array}$ & $\mathrm{kgm}$. \\
\hline $\begin{array}{l}\text { K. D. } \\
\text { J. M. } \\
\text { C. S. } \\
\text { H. F. } \\
\text { J. B. }\end{array}$ & $\begin{array}{r}1760 \\
670 \\
1850 \\
630 \\
900\end{array}$ & $\begin{array}{l}4020 \\
1270 \\
2880 \\
1180 \\
1360\end{array}$ & $\begin{array}{l}-1.0 \\
-0.2 \\
-1.0 \\
+0.6 \\
+0.2\end{array}$ & $\begin{array}{r}2030 \\
670 \\
1850 \\
630 \\
900\end{array}$ & $\begin{array}{r}2680 \\
1290 \\
3090 \\
960 \\
1650\end{array}$ & $\begin{array}{l}-0.1 \\
-0.5 \\
-1.0 \\
+0.2 \\
+0.4\end{array}$ \\
\hline
\end{tabular}

Later, in 2 patients whose generalized edema had disappeared but whose ascites was still present, identical albumin dosage failed to elicit a diuresis (Table III).

TABLE III

Comparison of effects of intravenous administration of 150 grams salt-poor albumin on average daily urine volumes in patients with ascites before and after loss of generalized edema

\begin{tabular}{|c|c|c|c|c|}
\hline \multirow[b]{2}{*}{ Patient } & \multicolumn{2}{|c|}{ With edema and ascites } & \multicolumn{2}{|c|}{ With ascites only } \\
\hline & $\begin{array}{l}\text { 3-day } \\
\text { control } \\
\text { period }\end{array}$ & $\begin{array}{c}\text { During } \\
\text { 3-day } \\
\text { treatment }\end{array}$ & $\begin{array}{l}\text { 3-day } \\
\text { control } \\
\text { period }\end{array}$ & $\begin{array}{c}\text { During } \\
\text { 3-day } \\
\text { treatment }\end{array}$ \\
\hline & ml. per $24 \mathrm{hrs}$. & ml. per $24 \mathrm{hrs}$. & ml. per $24 \mathrm{hrs}$. & ml. per $24 \mathrm{hrs}$. \\
\hline $\begin{array}{l}\text { J. M. } \\
\text { C. } . \text { S. }\end{array}$ & $\begin{array}{r}670 \\
1850\end{array}$ & $\begin{array}{l}1290 \\
3090\end{array}$ & $\begin{array}{r}820 \\
1940\end{array}$ & $\begin{array}{r}730 \\
1890\end{array}$ \\
\hline
\end{tabular}

As in the instance of single 50-gram injections of albumin, changes in body weight were inconstant in direction and losses did not approach diureses in magnitude (K. D., Figure 3 ).

c. Albumin for longer periods (totals 250 to 500 grams): Of the 3 patients treated with the larger doses of albumin (at a time when all had little or no edema), C. S. (Figure 4) showed no constant increase in urine volume, K. D. (Figure 3), a slight temporary increase, and J. B. (Figure 5), a more marked increase (700 $\mathrm{ml}$. average daily). Despite increased urine output, both the latter patients gained some weight during treatment. C. S. and $\mathrm{K}$. D. had previously received shorter courses of albumin; this was the first and only period in which patient J. B. received albumin. Changes in urine volumes and body weights are summarized in Table IV.
TABLE IV

Changes in urine volume and body weight following larger quantities of human albumin

\begin{tabular}{|c|c|c|c|c|c|}
\hline Patient & $\begin{array}{c}\text { Days of } \\
\text { treatment }\end{array}$ & $\begin{array}{l}\text { Total dose } \\
\text { of albumin }\end{array}$ & $\begin{array}{c}\text { Average } \\
\text { urine } \\
\text { volume } \\
\text { during } \\
\text { control } \\
\text { period }\end{array}$ & $\begin{array}{c}\text { Average } \\
\text { urine } \\
\text { volume } \\
\text { during } \\
\text { treatment }\end{array}$ & $\begin{array}{c}\text { Average } \\
\text { change } \\
\text { in } \\
\text { weight }\end{array}$ \\
\hline $\begin{array}{l}\text { K. D. } \\
\text { C. S. } \\
\text { J. B. }\end{array}$ & $\begin{array}{l}10 \\
27 \\
10\end{array}$ & $\begin{array}{c}\text { grams } \\
500 \\
425 \\
500\end{array}$ & $\begin{array}{c}\text { ml. per } 24 \\
\text { hrs. } \\
1820 \\
1850 \\
900\end{array}$ & $\begin{array}{c}\text { ml. per } 24 \\
\text { hrs. } \\
2110 \\
1740 \\
1660\end{array}$ & $\begin{array}{c}\text { kgm. per } \\
\text { day } \\
+0.2 \\
-0.1 \\
+0.3\end{array}$ \\
\hline
\end{tabular}

II. Effect of salt-poor concentrated albumin on serum and ascitic fluid proteins

The total protein and albumin values here presented were obtained by the Howe method (19), frequently supplemented by electrophoretic analysis on serum and plasma taken, during treatment, at least 8 hours after the last albumin injection.

a. Single infusion of 50 grams: The average of the rises in serum albumin (detailed in Table V) was 0.3 gram per cent. In general, total proteins changed little. The small hematocrit fall suggested moderate hemodilution.

b. Fifty grams daily for 3 days (total 150 grams): The uniform and striking increases in serum albumin (detailed in Table V and illustrated in the electrophoretic schlieren diagrams of the plasma proteins of K. D., Figure 6, H. F., Figure 7 , and C. S., Figure 8) averaged 0.8 gram per cent. The response of the total proteins varied in direction. The average drop in hematocrit was somewhat larger than following the 50-gram dose.

Estimates of total circulating albumin, calculated from changes in hematocrit and in plasma protein distribution by both Howe and electrophoretic methods, indicated that approximately 15 per cent of the albumin administered was retained in the blood stream, as determined on the morning following a standard injection during the previous day. Estimates of changes in total circulating globulin were inconstant in direction and sufficiently small both to fall within the considerable limits of error which the methods involve and to suggest that the globulins may have been neither increased nor decreased in total amount but merely diluted. This conclusion is further substantiated by the fact that ratios of the various electrophoretic globulin components to each other did not change following albumin therapy. 


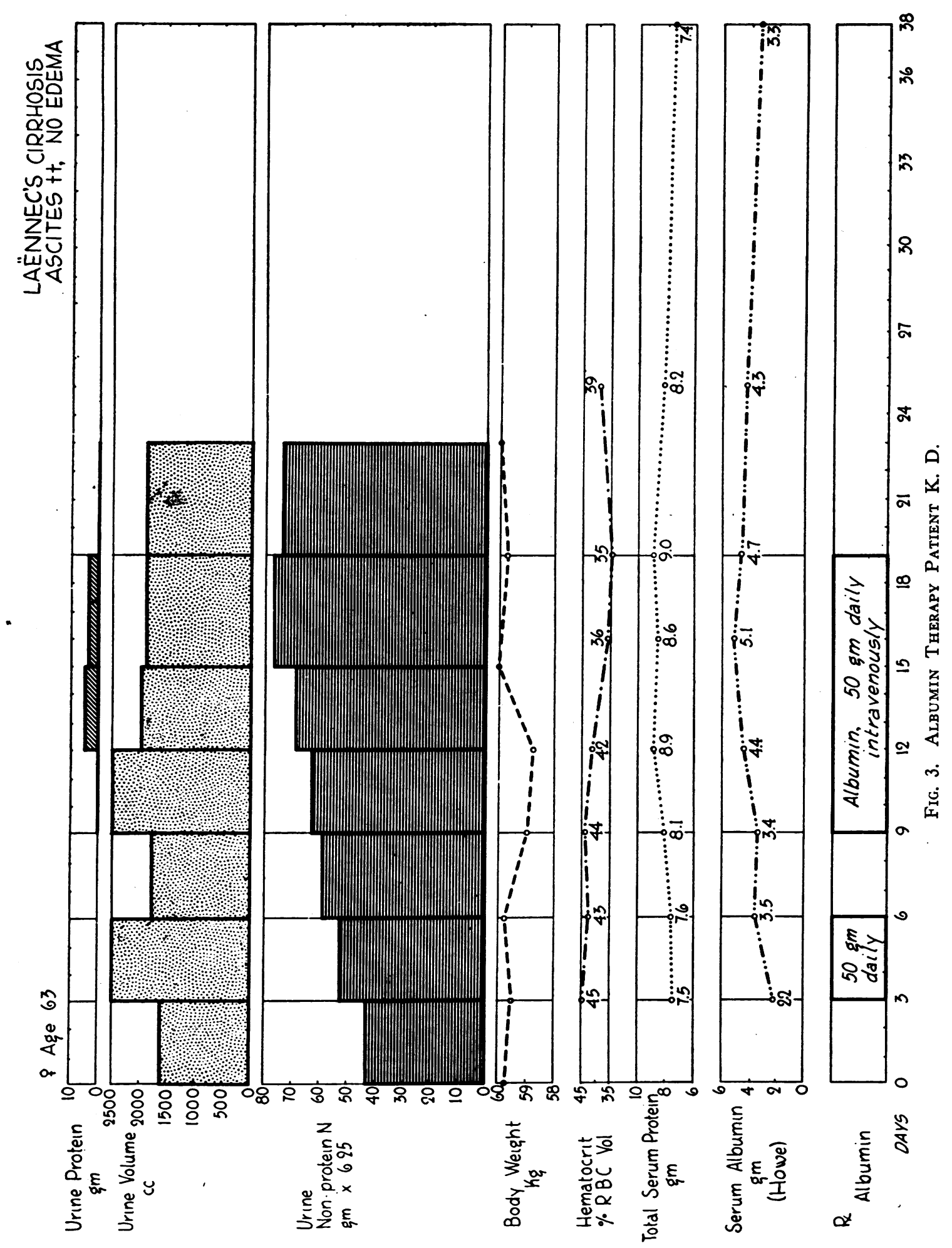




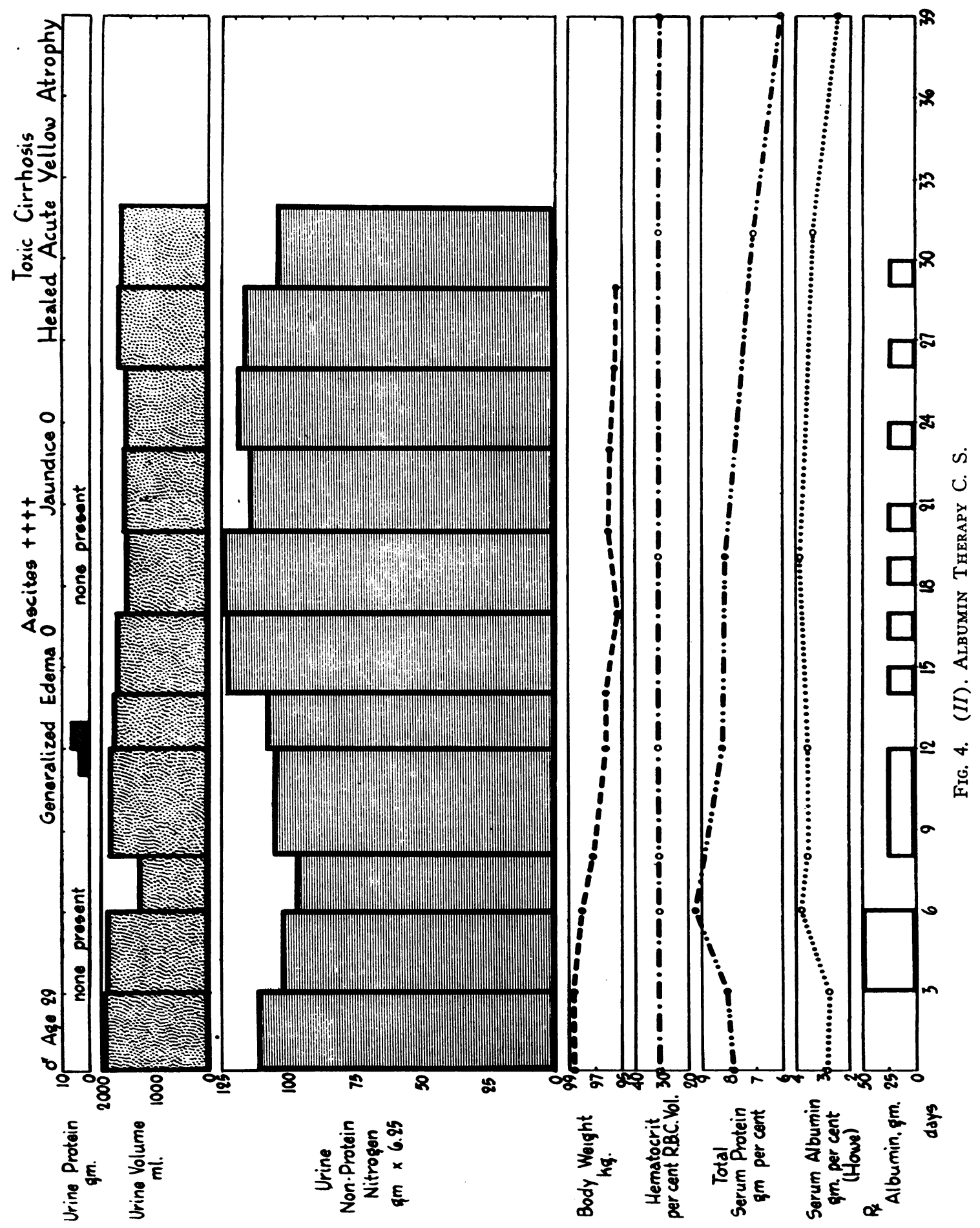




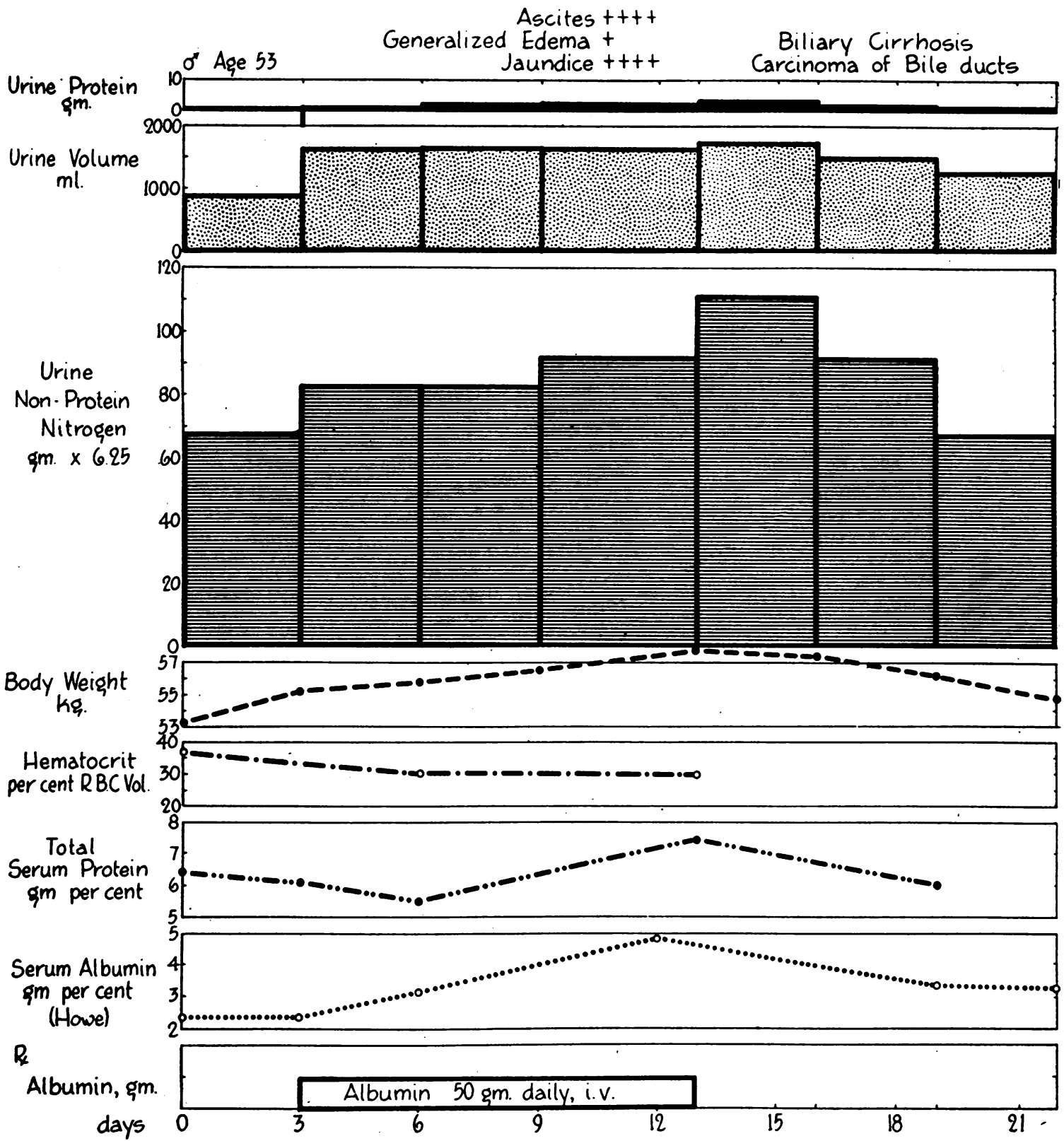

Fig. 5. Albumin Therapy Patient J. B.

Whereas the estimated increases in plasma volume following albumin therapy showed a wide spread (22), it is of interest to note that the average increase, viz. $14 \mathrm{ml}$., was of the order of magnitude predicted from in vitro osmotic pressure measurements (23) and from experiments following injection of albumin in patients with acute blood loss (24) and chronic glomerulonephritis (15).
The response of the proteins of ascitic fluid to this dosage comprised a small increase (approximately 0.5 gram per cent) in total protein, associated with a striking increase in the albumin fraction. The continued rise in the proportion of the albumin fraction after the serum albumin had begun to fall is well illustrated in the electrophoretic schlieren diagrams of plasma and ascitic proteins of patient H. F. (Figure 7). During ther- 
TABLE V

Changes in serum protein and hematocrit after intravenous injection of concentrated human albumin solutions in varying dosage

\begin{tabular}{|c|c|c|c|c|c|c|c|c|c|}
\hline \multirow{2}{*}{ Patient } & \multirow{2}{*}{$\begin{array}{l}\text { Dose of } \\
\text { albumin }\end{array}$} & \multicolumn{2}{|c|}{ Serum albumin } & \multicolumn{2}{|c|}{ Serum globulin } & \multicolumn{2}{|c|}{ Total serum protein } & \multicolumn{2}{|c|}{ Hematocrit } \\
\hline & & Before & After & Before & After & Before & After & Before & After \\
\hline & grams & $\begin{array}{c}\text { grams per } \\
100 \mathrm{ml} .\end{array}$ & $\begin{array}{c}\text { grams per } \\
100 \mathrm{ml} .\end{array}$ & $\begin{array}{l}\text { grams per } \\
100 \mathrm{ml}\end{array}$ & $\begin{array}{l}\text { grams per } \\
100 \mathrm{ml} .\end{array}$ & $\begin{array}{c}\text { grams per } \\
100 \mathrm{ml} .\end{array}$ & $\begin{array}{l}\text { grams per } \\
100 \mathrm{ml} .\end{array}$ & $\begin{array}{c}\text { per cent } \\
\text { packed cell } \\
\text { solume }\end{array}$ & $\begin{array}{c}\text { per cent } \\
\text { packed cell } \\
\text { solume }\end{array}$ \\
\hline K. D. & $\begin{array}{r}50 \\
150 \\
500\end{array}$ & $\begin{array}{l}1.6 \\
2.2 \\
3.4\end{array}$ & $\begin{array}{l}2.0 \\
3.5 \\
4.7\end{array}$ & $\begin{array}{l}4.6 \\
4.7\end{array}$ & $\begin{array}{l}4.1 \\
4.3\end{array}$ & $\begin{array}{l}6.8 \\
8.1\end{array}$ & $\begin{array}{l}7.6 \\
9.0\end{array}$ & $\begin{array}{l}47 \\
45 \\
44\end{array}$ & $\begin{array}{l}44 \\
43 \\
33\end{array}$ \\
\hline J. M. & $\begin{array}{r}50 \\
150\end{array}$ & $\begin{array}{l}1.3 \\
1.7\end{array}$ & $\begin{array}{l}1.8 \\
2.3\end{array}$ & 2.8 & 2.2 & 4.5 & 4.5 & $\begin{array}{l}20 \\
20\end{array}$ & $\begin{array}{l}18 \\
18\end{array}$ \\
\hline C. S.* & $\begin{array}{r}50 \\
150 \\
250\end{array}$ & $\begin{array}{l}3.0 \\
1.9 \\
2.8\end{array}$ & $\begin{array}{l}3.2 \\
2.5 \\
3.6\end{array}$ & $\begin{array}{l}4.5 \\
5.3\end{array}$ & $\begin{array}{l}4.1 \\
4.9\end{array}$ & $\begin{array}{l}6.4 \\
8.1\end{array}$ & $\begin{array}{l}6.6 \\
8.3\end{array}$ & $\begin{array}{l}31 \\
33 \\
31\end{array}$ & $\begin{array}{l}30 \\
31 \\
31\end{array}$ \\
\hline H. F. & $\begin{array}{r}50 \\
150\end{array}$ & $\begin{array}{l}2.3 \\
1.9\end{array}$ & $\begin{array}{l}2.7 \\
2.8\end{array}$ & 5.4 & 3.6 & 7.3 & 6.4 & $\begin{array}{l}36 \\
39\end{array}$ & $\begin{array}{l}34 \\
32\end{array}$ \\
\hline J. B. & $\begin{array}{l}150 \\
500\end{array}$ & $\begin{array}{l}2.3 \\
2.3\end{array}$ & $\begin{array}{l}3.1 \\
4.8\end{array}$ & $\begin{array}{l}3.8 \\
3.8\end{array}$ & $\begin{array}{l}2.4 \\
2.6\end{array}$ & $\begin{array}{l}6.1 \\
6.1\end{array}$ & $\begin{array}{l}5.5 \\
7.4\end{array}$ & $\begin{array}{l}35 \\
35\end{array}$ & $\begin{array}{l}29 \\
30\end{array}$ \\
\hline
\end{tabular}

* This study was carried out when patient was much improved, as evidenced by increased initial serum albumin level.

apy the albumin contribution to the plasma diagram rose from 26 to 43 per cent; in the ensuing 5 days it fell to 36 per cent, while the ascitic fluid albumin contribution, which during therapy had risen from 36 per cent to 47 per cent, increased slightly.

c. Albumin for longer periods (totals 250 to 500 grams): In 3 patients the increases in serum albumin were approximately $1.3,0.8$, and 2.5 grams per cent (Table V). The maintenance of this increase for a considerable period following withdrawal of therapy is well illustrated in the instance of patient K. D. (Figure 3). The total proteins rose in varying degree; the highest level attained was 9.0 grams per cent in patient $K$. D. whose plasma electrophoretic schlieren diagram (Figure 6 ) showed an albumin contribution of 61 per cent, 6 per cent greater than the average in normal pooled plasmas studied in this laboratory (25). In this patient the proportion of administered albumin remaining in the circulation at the end of the period of therapy was approximately 25 per cent, as calculated from measurements of plasma volume by the Evans blue method and distribution of the plasma proteins. Estimates for the other 2 patients indicated that the proportion of albumin retained in the circulation did not exceed this figure.
In Figure 9, in which increase in serum albumin level (grams per cent) is plotted against total dose of albumin, it may be seen that in the range of dosage studied, an approximately linear relation obtains. Thus, large doses were proportionally more effective than small in restoring to normal, or indeed higher than normal, the serum albumin levels in this group of cirrhotics.

\section{Proteinuria following albumin administra- tion in cirrhotic patients}

The 50-gram dose did not either induce urinary protein excretion or increase the minimal spontaneous proteinuria seen in certain patients during control periods. Although proteinuria of slight degree occasionally followed administration of 150 grams, only during the longer periods of therapy when the serum albumin had attained normal or greater than normal levels did significant proteinuria result. Thus, patient C. S. (Figure 4) excreted 11 grams of protein on the last 2 days of a 5-day period of therapy (250 grams) at a time when his total plasma proteins varied between 8.3 and 9.0 grams per cent and his serum albumin level averaged over 3.6 grams per cent. An even larger amount of urinary protein (36 grams) was excreted by patient $\mathrm{K}$. D. during the administration 


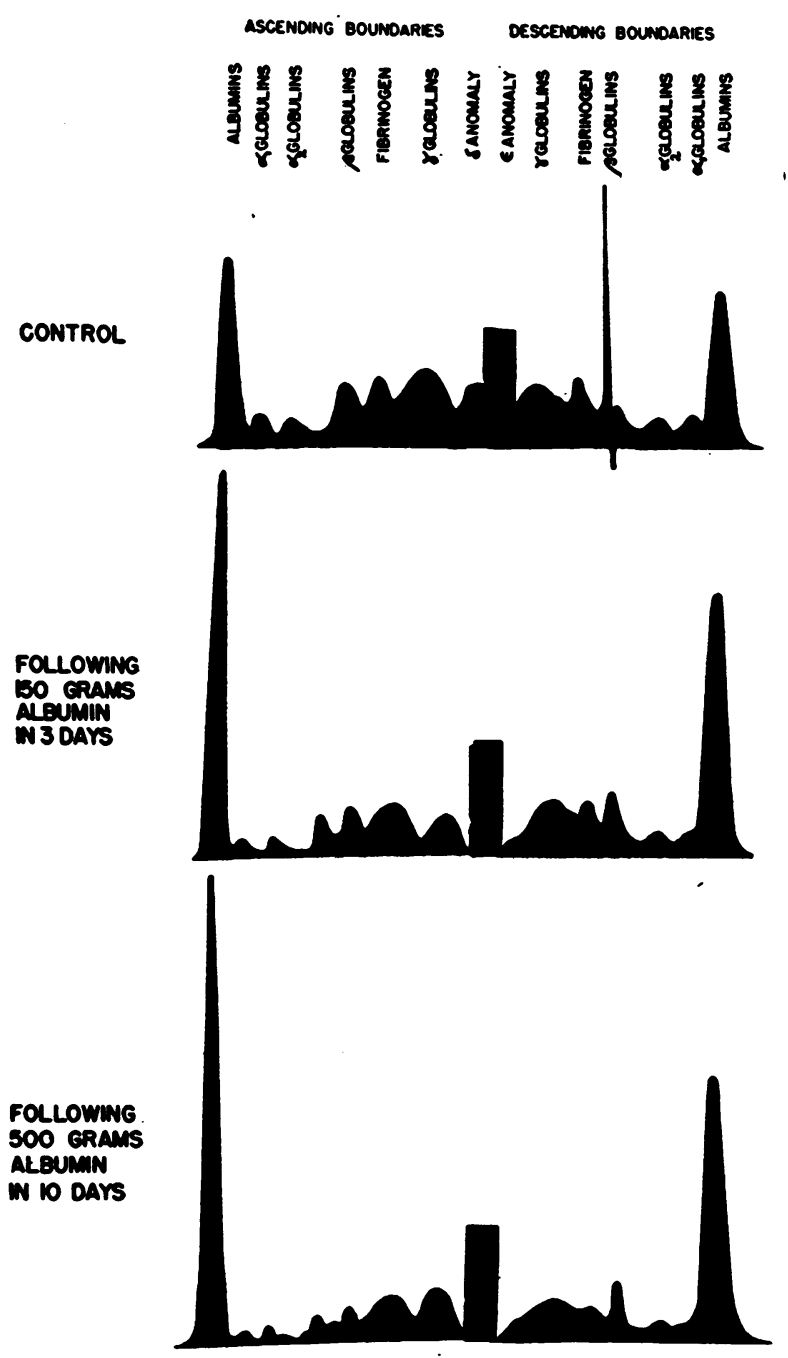

Fig. 6. Plasma Patient K. D.

of $\mathbf{5 0 0}$ grams of albumin in 10 days, at which time serum protein and albumin levels were correspondingly higher, i.e. 8.2 to 9.0 grams per cent and 4.5 to 5.0 grams per cent respectively (Figure 3). J. B., who during the control period showed slight spontaneous proteinuria, also excreted approximately 30 grams of protein in his urine during the latter part of the administration of 500 grams of albumin. The maximum excretion in this patient was attained at a somewhat lower total protein but a comparable serum albumin concentration (7.4 and 4.9 grams per cent respectively).

These increases in proteinuria in all instances disappeared within a few days after therapy.
IV. Effect of albumin administration on severity of ascites

Although many times during the course of these experiments the patients with severe ascites stated that their abdomens felt less tense following administration of albumin in dosage between 50 and 150 grams, by clinical examination no change in degree of ascites was evident.

During the longer courses of therapy, despite absence of change in body weight, all clinical evidence of ascites in both patients $K$. D. and C. S. had disappeared. This change, however, cannot be unequivocally ascribed to therapy in either case. In the instance of patient $\mathrm{C}$. S. it may have represented the spontaneous diuresis seen in course of recovery from subacute yellow atrophy which was superimposed on a severe toxic cirrhosis, and in K. D. it may have represented the spontaneous diuresis often seen at varied periods following institution of bed rest and adequate nutritional regimen in Laennec's cirrhosis of moderate degree.

The absence of response of ascitic fluid to 10day therapy ( 500 grams of albumin) in patient $\mathrm{J}$. B. is readily understandable in the light of the findings of peritoneal metastases at autopsy.

\section{Nitrogen balance ${ }^{4}$}

a. Single infusion of 50 grams: Nitrogen balance studies (Table VI) indicated that only 16

TABLE VI

Summary of nitrogen balance studies following albumin administered intravenously (hepatic cirrhosis)

\begin{tabular}{c|c|c|c}
\hline \hline $\begin{array}{c}\text { Number of } \\
\text { patients }\end{array}$ & $\begin{array}{c}\text { Dose of } \\
\text { albumin }\end{array}$ & $\begin{array}{c}\text { Retention of } \\
\text { albumin }\end{array}$ & $\begin{array}{c}\text { Retention of } \\
\text { albumin }\end{array}$ \\
\cline { 2 - 3 } & grams & grams & per cent \\
5 & 50 & 42 & 84 \\
5 & 150 & 122 & 81 \\
1 & 425 & 170 & 40 \\
2 & 500 & 280 & 56 \\
\hline
\end{tabular}

per cent of the administered protein nitrogen was excreted during the day of treatment and 3 successive control days.
b. Fifty
grams
daily
for 3 days
(total 150

4 Nitrogen balance studies are reported on the basis of changes in urine nitrogen excretion, since nitrogen intake remained constant throughout the experiment and stool nitrogen excretion was assumed to be 15 per cent of ingested nitrogen. 
$\stackrel{\infty}{m}$

F

q
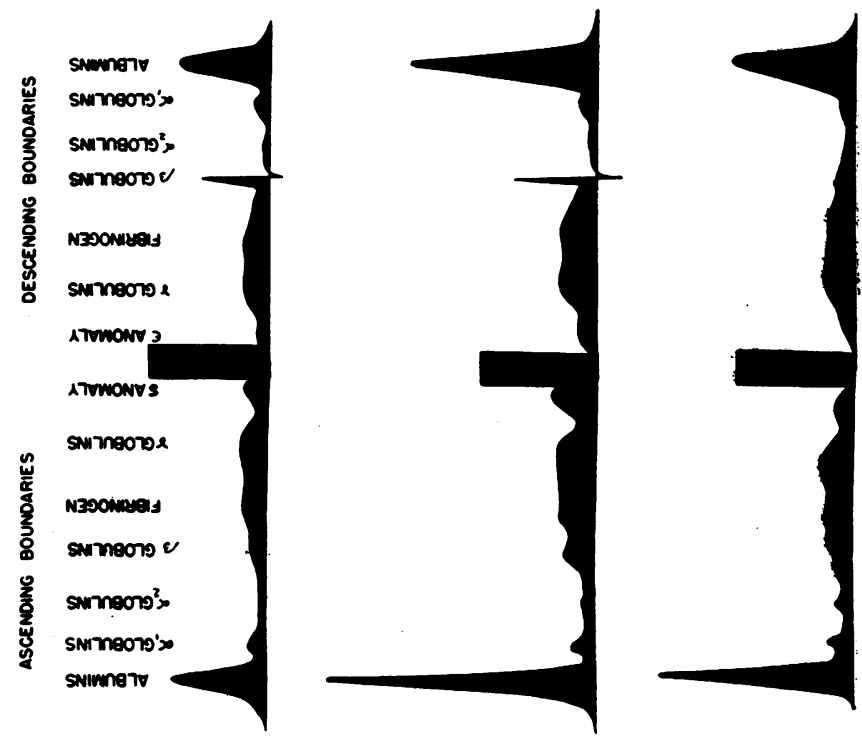

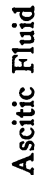<smiles>[CH][As]C</smiles>

q

$\ddot{m}$

坛

出

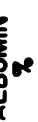

$\stackrel{\sim}{N}$
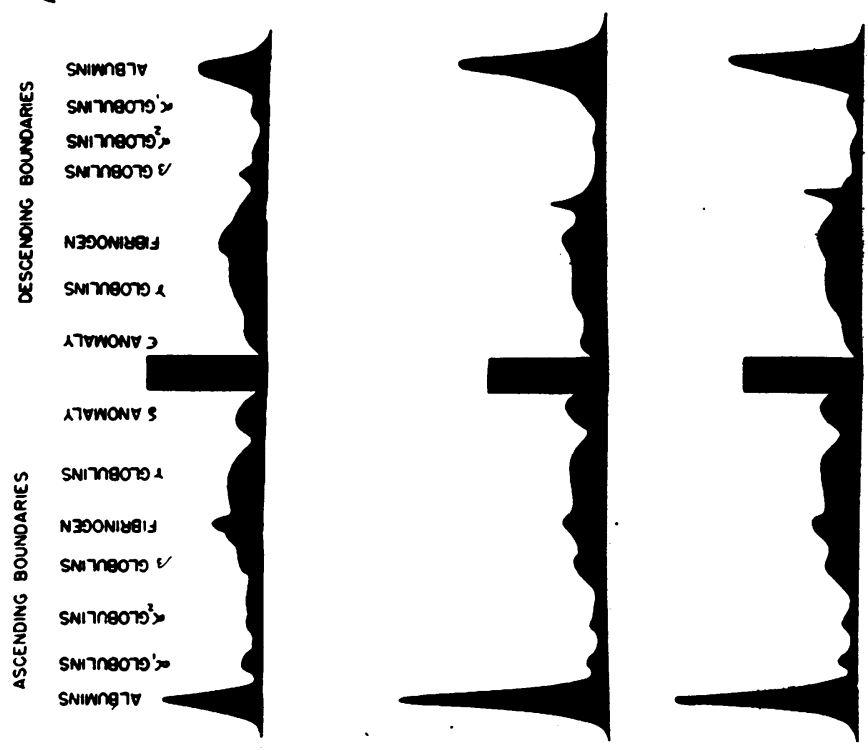

总
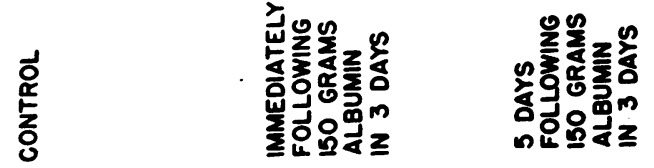

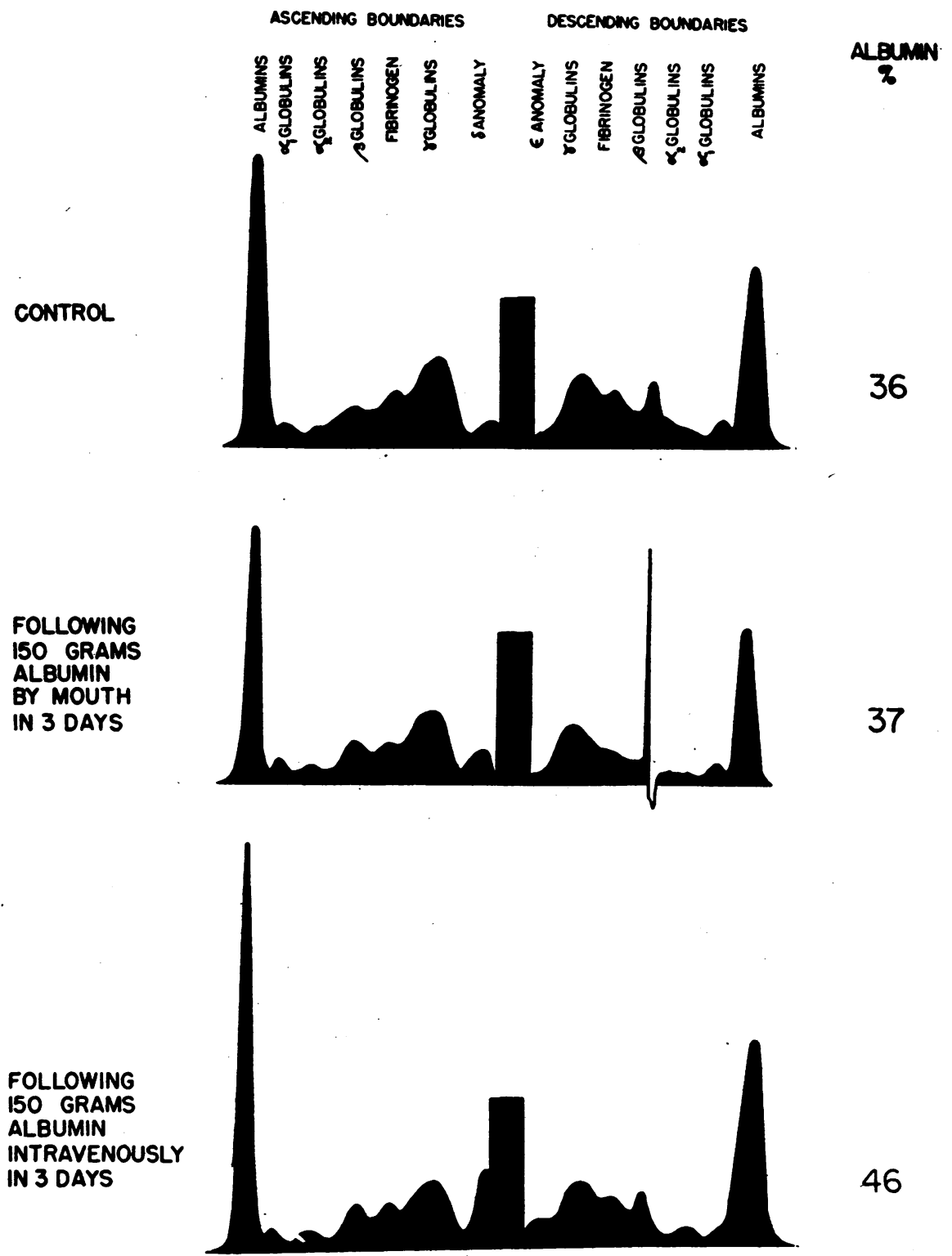

Fig. 8. Plasma Patient C. S.

grams): In 5 experiments, the average daily increase in nitrogen excretion during the 3-day period of therapy amounted to 1.3 grams, the equivalent of 8 grams of protein daily or some 15 per cent of the protein administered. Thus in this group of patients already in slightly positive nitrogen balance, a markedly positive balance was attained. In 3 patients, followed for 3 to 6 days after cessation of therapy, approximately 33 per cent more of the administered nitrogen was ex- creted in the urine. These relations are illustrated in Figures 2 and 3 (patients C. S. and K. D.).

c. Albumin for longer periods: Patient J. B., who had not been given smaller doses of albumin previously, retained approximately 75 per cent of the 500 grams injected over a period of 10 days. Patients K. D: and C. S., who received 500 and 425 grams respectively, and who had been previously treated for shorter periods with albumin, retained 38 and 40 per cent respectively. 


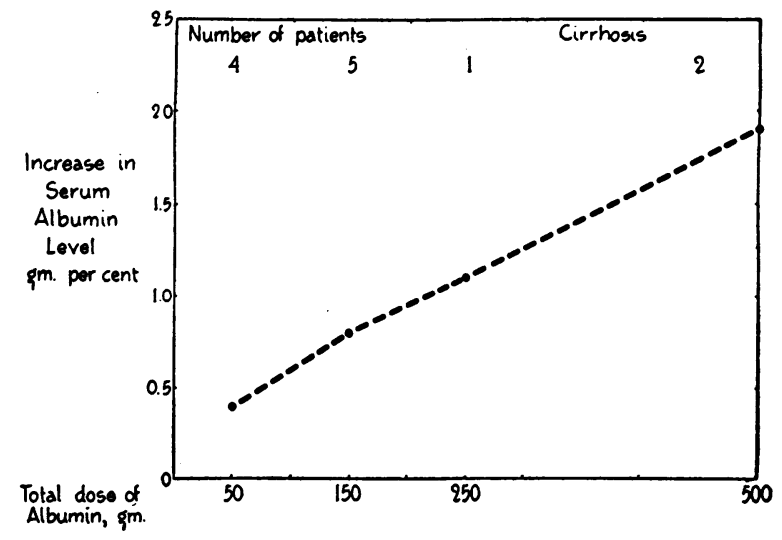

Fig. 9. Changes in Serum Albumin Level Following Intravenous Administration of a Concentrated Solution of Salt-Poor Human Albumin

VI. Comparison between effects of 150 grams of salt-poor albumin administered intravenously and orally on serum albumin levels and on nitrogen balance

This comparison was made on 3 occasions in 2 patients (C. S. and J. B.). The contrast between the uniform failure of oral administration to affect either total protein or albumin level and the strik- ing effect of intravenous administration on these levels is illustrated in Figures 10 (determinations by Howe method) and 8 (determinations by electrophoresis).

The contrast between urinary nitrogen excretion following administration by both routes is illustrated in Figure 11 (patient J. B.). Here it can be seen that nitrogen losses following orally administered albumin were far greater than following intravenous injection.

\section{DISCUSSION}

In view of the fact that no great differences were found between the effects of albumin on the various types of cirrhosis in this group, it is of interest to consider them in contrast with parallel effects in the nephrotic stage of chronic Bright's disease.

In both conditions there appeared to be a fairly clear-cut correlation between the extent of edema and the ability of albumin to increase urine volume. $^{5}$

5 Presuming the increment in urinary nitrogen excretions following short-term albumin administration were entirely in the form of urea, this would amount to a daily

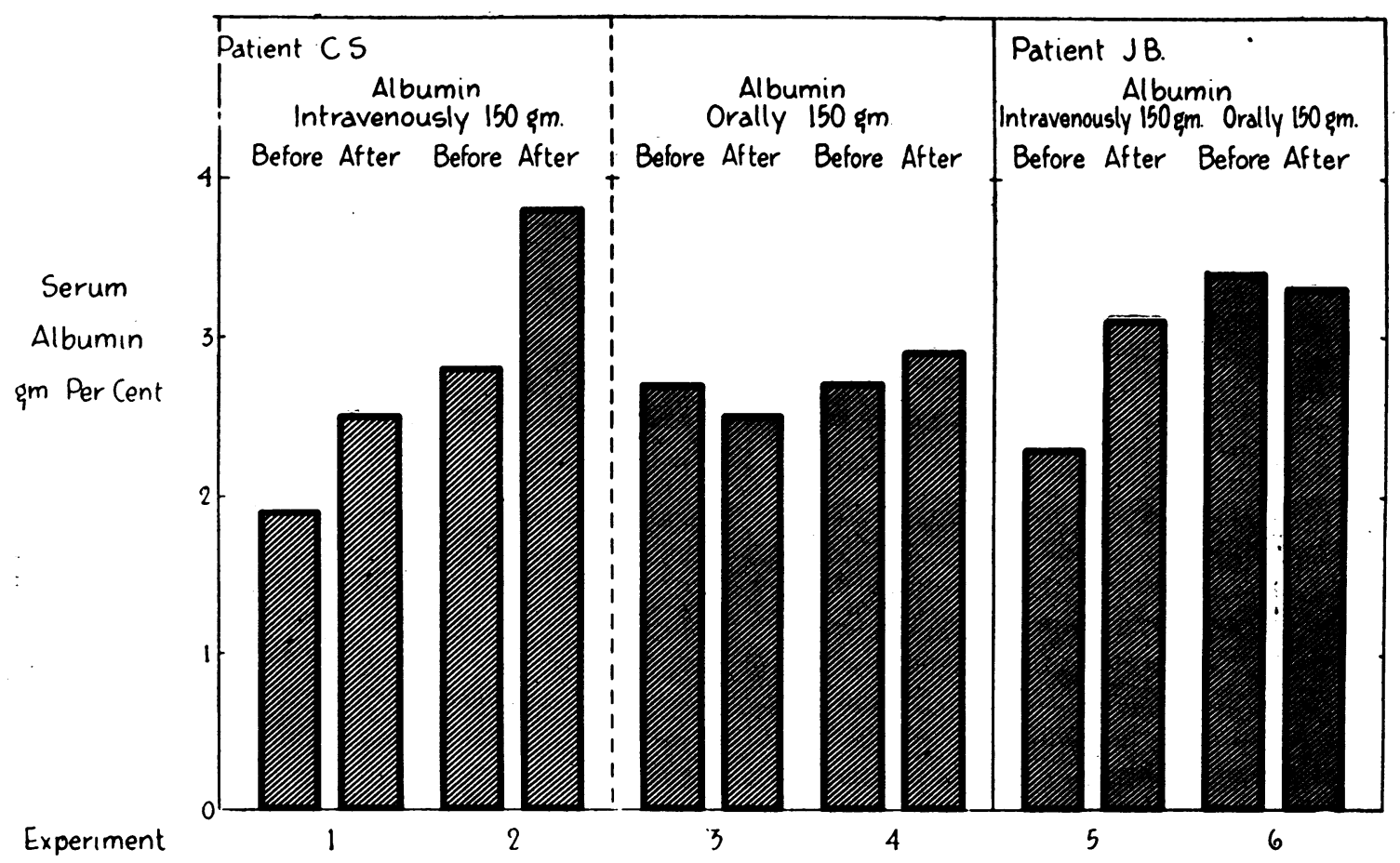

Fig. 10. A Comparison Between the Effect of Albumin Administered Intravenously and Orally on Serum Albumin Level 


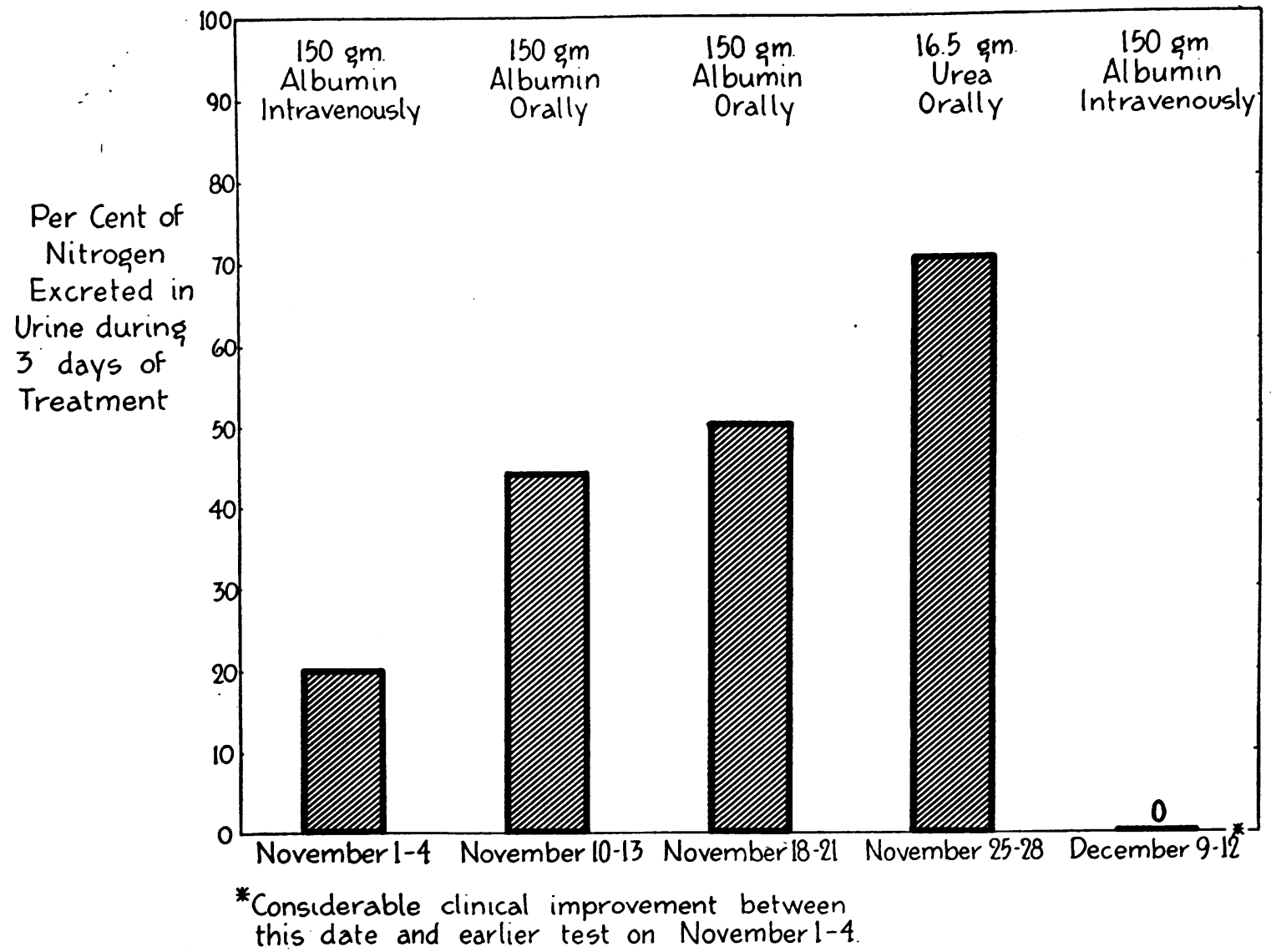

Fig. 11. Urinary Nitrogen Excretion Following the Administration of Equivalent Quantities of Protein Intravenously and Orally

From the nearly uniform occurrence of increases in urine volume following short-term therapy in cirrhotic edema, the ability of albumin to maintain such increases over longer periods cannot be inferred, and unfortunately, available material was insufficient to permit experiments directed at this question. In the experiments involving dosages as high as $\mathbf{5 0 0}$ grams and periods as long as 10 days, the patients showed ascites but no significant edema.

A striking divergence, however, between nephrotic and cirrhotic edematous patients lay in the response of body weight to therapy. In the former group, the increases in urine volume following

increment over control periods of 3 to 4 grams of urea, a dose which when administered orally to edematous patients is usually ineffective as a diuretic. Thus, the increases in urine volume can not be ascribed to urea excretion. The data obtained in this study do not elucidate the mechanism of these increases. albumin were regularly accompanied by decreases in body weight of equivalent magnitude; in the latter, such increases of urine volume were uniformly unassociated with weight loss.

The lack of correlation between increases in urine volume and changes in body weight cannot be entirely ascribed to water associated with protein retained within or without the blood stream. In the nephrotic state, the degree of retention of albumin, in dosage of 50 grams a day for 1 to 3 days, approximated 50 per cent (15). The corresponding figure for the cirrhotic group is 80 per cent. Thus, for short periods of therapy, the difference in daily protein retention is about 10 grams. If it be assumed that the ratio of tissue water to tissue protein be in the neighborhood of 20 per cent, this will account for only a $50 \mathrm{ml}$. difference in water retention between the two groups. The actual difference is many times this figure. 
The observation of Ralli and her co-workers (26) that total protein, serum albumin, and calculated osmotic pressure levels were identical in a cirrhotic patient during a phase of ascitic fluid formation, untreated, and during a phase without ascites, following institution of Patek's regimen (1), together with the finding of increased amounts of antidiuretic substances in the urine of cirrhotic patients with ascites in contrast to cirrhotic patients without ascites, clearly demonstrates that the albumin level is not the only factor governing formation. It is also possible, though as yet not demonstrated experimentally, either by histology or pressure measurements, that among the effects of the Patek regimen is a diminution of scarring in the portal spaces and thus a decrease in effective portal filtration pressure. A schematic representation of possible interactions of hypoalbuminemia in the clinical pattern is presented in Figure 12.

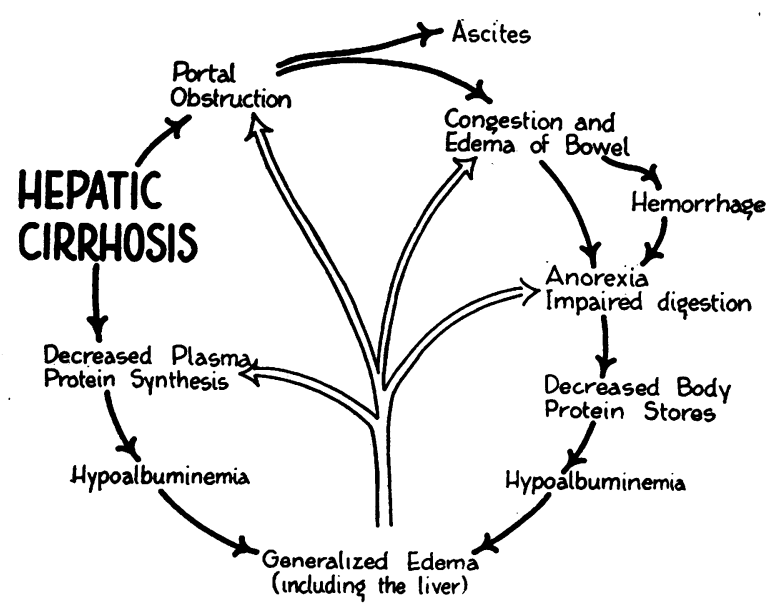

Fig. 12. Hepatic Cirrhosis

It is of interest that the selective increase of gamma globulins in the cirrhotic group did not show any fall beyond that attributable to pure dilution following albumin administration.

Although in liver disease of a more acute nature heterogenetic antibodies have been found (27), chronic hepatic cirrhosis is unique among those in which elevated gamma globulins are found, in that neither infection nor abnormal immunological response is believed to be concerned in pathogenesis.

It has been suggested (21) that this high gamma globulin level may be a compensatory mechanism to offset the diminished plasma colloid osmotic pressure consequent upon hypoalbuminemia. The failure of the total circulating gamma globulins to decrease following return of the serum albumin level to normal does not support, although it does not disprove, this concept.

Other possible mechanisms suggested by the known extrahepatic production of antibodies and the recent finding of extrahepatic intracellular gamma globulins (28) will become subject to experimental approach when a preparation of gamma globulin suitable for intravenous use becomes available.

The most striking difference between the responses of the cirrhotic and the chronic glomerulonephritic patients to albumin was the capacity of this agent to induce serum albumin levels not only far higher in the former than in the latter but far more sustained.

Thus, dosage of 150 grams over 3 days produced average serum albumin rises twice as great in cirrhosis as in the nephrotic group. In the severe nephrotic state the maximum rise in serum albumin level (1 gram per cent), attained with a dosage of 500 grams over 10 days, was not further increased by dosage as large as 1,000 grams over 20 days. In the cirrhotic group, 500 grams over 10 days yielded serum albumin rises twice the nephrotic maximum, and sufficient not only to restore the albumin level to normal, but to raise total protein levels, in view of hyperglobulinemia, considerably above normal. At this latter point only did albuminuria, a constant route of protein loss in the nephrotic group, become significant in cirrhotics. In severe nephrosis the albumin level fell to pretreatment values within 10 days following the most extensive albumin treatment $(1,500$ grams over 30 days). In the cirrhotics, following one-third the dosage, the time required for fall to initial level was more than three times as long.

From the standpoint of nitrogen balance, the cirrhotic group retained on an average 20 per cent more of the administered protein during both short and long periods of treatment than did the glomerulonephritic group.

Thus, in the treatment of cirrhotic hypoalbuminemia, total albumin dosage will ultimately prove far less than that required in the nephrotic 
state. More extended studies than these may indicate that optimal dosage is quite different from that here used, namely, intensive initial administration until the albumin level reaches normal, followed by smaller doses at intervals sufficient to maintain the desired level.

Again, initial more intensive and more prolonged therapy may yield more definitive evidence on the effectiveness of albumin in the mobilization of ascites. The disappearance rates here encountered, which proved too slow to permit interpretation, might, in view of the slow attainment of equilibrium found in distribution of proteins between plasma and ascitic fluids, ${ }^{8}$ be speeded up by a sudden and continued elevation of plasma albumin. ${ }^{7}$

In the various forms of clinical liver disease, there would appear from these limited studies to be two outstanding groups in whom long-term albumin therapy may ultimately prove to have great and, indeed, perhaps unique efficacy:

(1) The severe cirrhotics, unable, though in positive nitrogen balance, to increase serum albumin: For these patients, in whom progression of disease is slow, and who may be studied under standard conditions for long periods, the raising and maintenance of normal albumin levels might result in decreased incidence of abdominal taps, together with the disability associated with ascites.

(2) The severest cases of continued hepatitis whose dietary intake is compromised by anorexia and for whom albumin, if need be supplemented by other substances, might provide means of attaining positive nitrogen balances and normal serum albumin levels, and thus perhaps shorten time required for healing and diminish ultimate degree of hepatic damage (31).

The establishment of such therapeutic values for albumin will require far wider use in wellcontrolled series.

\footnotetext{
6 This is probably attributable to the relatively small capillary surface area per unit volume of ascitic fluid, and to the relatively high diffusion constants of the proteins. The diffusion constants of serum albumin and serum gamma globulin have been compared with those of the sodium ion and of glucose in Table $I$ of the first paper of this series (29).

7 Gibson (30) has recently attained promising results employing initial daily doses as large as twice those used here.
}

\section{SUMMARY AND CONCLUSIONS}

Salt-poor concentrated human serum albumin has been administered intravenously for periods varying in the main between 1 and 10 days at a dosage of 50 grams a day to a group of 5 patients representing several types of hepatic cirrhosis. The patients were maintained on a diet adequate in calories, containing at least 1 gram of protein per kgm. of body weight, and less than 70 grams of fat per day, with supplementary vitamins and liver. Intake of sodium chloride was restricted.

In the presence of generalized edema, therapy of 1 to 3 days yielded striking increases in urine volume over control periods. The weight loss associated with the diuresis was less than would have been expected from the increase in urine volume. In the same patients, in the absence of generalized edema, short periods of albumin treatment failed to increase urine volume despite the presence of ascites. The finding of a slow attainment of equilibrium between plasma and ascitic fluid proteins suggests that more intensive and prolonged treatment must be carried out before any conclusion can be reached regarding the ability of albumin to mobilize ascitic fluid.

Uniform and striking increases in serum albumin levels followed albumin administration. These were proportional to dosage. Final levels were higher, and rates of decline far slower, than observed in the nephrotic syndrome. In consequence of hyperglobulinemia, elevation of albumin levels to normal by dosage of 500 grams over 10 days resulted in total protein occasionally above normal.

Effect of albumin administration on globulin components, as studied by electrophoretic analysis, appeared to be merely dilution.

Little or none of the albumin administered intravenously was excreted in the urine. Balance studies indicated that approximately 80 per cent of the injected albumin was retained when 50 to 150 grams were administered; with larger doses, approximately 50 per cent was retained. These figures exceed the corresponding figures in the nephrotic syndrome by approximately 20 per cent.

In contrast to the effectiveness of albumin administered intravenously in raising serum albumin level and increasing positive nitrogen balance, oral administration was ineffective. 
It is suggested that the promising fields for albumin therapy in liver disease lie (1) in severe cirrhotics who on dietary therapy alone can maintain positive nitrogen balance but cannot raise the serum albumin level, and (2) in long-continued hepatitis where anorexia gravely compromises dietary intake and thus prevents attainment of positive nitrogen balance and normal albumin levels.

\section{CASE HISTORIES AND INITIAL CLINICAL FINDINGS}

K. D. (M-66458), a 63-year-old Irish housewife, entered the Peter Bent Brigham Hospital because of swelling of legs and abdomen of 3 weeks' duration.

There was no chemical exposure. Her diet had been normal in quantity and distribution. There had been no history of liver or biliary tract disease. Following an acute, painless febrile illness of 1 month's duration 3 years before admission, characterized by anorexia, nausea and vomiting, yellow skin and dark urine, persistent anorexia led both to a decrease in meat intake, and 18 months before admission to an increase of beer consumption from a previous single glass to 4 to 5 quarts a day.

Six months prior to admission, occasional nausea further diminished food intake without impairing appetite for beer. One week before admission abdominal paracentesis had yielded 10 liters of fluid.

Physical examination: A well-developed, poorly nourished white woman showed moderate emaciation of the upper extremities and thorax, a swollen abdomen and pitting edema of genitalia, sacrum and legs. Icterus, spider angiomata and dermatitis were absent. Beyond a loud systolic murmur over the entire precordium, the heart was normal. The lungs were clear. Diaphragms were high. The abdomen was strikingly distended with fluid. There was no caput medusae. A firm, smooth, non-tender liver edge was palpable by ballottement 3 fingers below the right costal märgin. Spleen was not felt. There were some hemorrhoidal tabs.

Laboratory data: Blood Hinton negative. Urines: Negative save for transitory $1+$ bilirubinuria. Blood: Hematocrit 46, hemoglobin 14.2 grams per cent, sedimentation rate $41 \mathrm{~mm}$. per hour, white cells 3,900 per c.mm., differential normal. Total protein 6.5 grams per cent, albumin 1.6 grams per cent, globulin 4.9 grams per cent (Howe method). Bromsulfthalein 25 per cent retention in 50 minutes. Prothrombin time 42 seconds, control 30 seconds.

$X$-ray examination of the esophagus: No evidence of varices.

Clinical diagnosis: Laennec's cirrhosis.

J. M. (M-61421), a 70-year-old retired streetcar conductor, with known mild diabetes, hypertension and arteriosclerotic heart disease, entered the Peter Bent Brigham Hospital because of abdominal swelling, fatigue and anorexia.
There had been no symptoms of liver or biliary tract disease, no chemical exposure and no alcohol intake. Prior to treatment of diabetes, 2 years before admission, with a 1,000-calorie diet containing 60 grams of protein and supplementary vitamins, food intake had been normal in quantity and distribution.

Four months before admission in course of an examination for rectal bleeding due to hemorrhoids and resultant hypochromic anemia, asymptomatic ascites and pitting edema of the ankles were found. Peritoneoscopy disclosed a liver edge sharp, irregular, and hobnail in appearance. No biopsy was done. Bromsulfthalein retention was 28 per cent at $\mathbf{4 0}$ minutes; cephalin flocculation was negative. $\mathrm{X}$-ray examination disclosed no esophageal varices.

In the intervening months abdominal swelling recurred. Anorexia progressed to nausea and vomiting accompanied by intermittent diarrhea and bouts of steady mid-line lower abdominal pain relieved only by vomiting. There were no chills, fever, or jaundice.

Physical examination: A pale elderly man, with moderate wasting of the upper trunk and a strikingly distended abdomen, was in no respiratory distress. There was no icterus. There was a single spider angioma on the right cheek. Despite edema of the legs, back and abdominal wall, the lungs were clear. The heart was enlarged to percussion with a moderate systolic murmur and a slow regular rhythm without pulse deficit. The abdomen was tautly distended with fluid. Rectal examination revealed hemorrhoids.

Laboratory data: Blood Hinton negative. Urines negative. Blood: Red cells 2,000,000 per c.mm., hematocrit 20, white cells 5,000 per c.mm., differential normal. Total protein 4.3 grams per cent, albumin 1.3 grams per cent, globulin 3.0 grams per cent (Howe method). Bromsulfthalein 40 per cent retention in 30 minutes. Prothrombin time 30 seconds, control 45 seconds. Cephalin flocculation $3+$ in 24 hours. Stool guaiac $1+$ to $4+$. Ascitic fluid: Histological examination of centrifuged sediment negative for neoplastic cells.

Clinical diagnosis: Laennec's cirrhosis.

C. S. (M-67002), a 29-year-old single male of Italian extraction, entered the Peter Bent Brigham Hospital because of marked abdominal distention, edema, shortness of breath, jaundice, diarrhea, and anorexia.

Past history revealed no previous jaundice or evidence of biliary tract disease. From a daily tumbler of wine per day at the age of 6 , alcohol consumption had increased to 6 to 8 quarts of beer daily in the 4 months prior to admission. For the past 10 years he had been exposed to carbon tetrachloride, tetrachlorethylene, and benzol in a cleaning establishment. Although his diet steadily deteriorated in quantity and distribution, particularly with reference to meat and protein-rich foods, he became obese.

As his weight passed 220 pounds, dyspnea on exertion appeared and, in the three months before admission, anorexia, jaundice, sporadic diarrhea and progressive edema. Urine became scanty and dark brown. Stools were not clay colored. 
Physical examination: A tremendously obese young man was restless, on the edge of disorientation, and uncomfortable due both to moderate dyspnea and an enormously swollen abdomen. Skin and sclerae were icteric. There was no dermatitis. Hands, legs, and scrotum were edematous. There were 2 small spider angiomata on the upper trunk. Breasts were large. Hair was sparse in quantity but of normal male distribution. There was a grade I systolic murmur over the entire precordium; otherwise the heart was normal. Lungs were clear except for occasional moist râles at the right base posteriorly. Diaphragms were high bilaterally. The abdomen showed a clean-cut fluid wave and large periumbilical veins. No organs were palpable.

Laboratory data: Blood Hinton negative. Urines: Negative save for sporadic slight proteinuria and bilirubinuria, and hematuria. Blood: Red cells $3,700,000$ per c.mm., hematocrit 38, sedimentation rate $54 \mathrm{~mm}$. per hour, white cells 8,000 per c.mm., differential normal. Total protein 6.3 grams per cent, albumin 1.3 grams per cent, globulin 5.0 grams per cent (Howe method). Icterus index 40 . Bromsulfthalein 70 per cent retention at 40 minutes. Cephalin flocculation $4+(24$ hours $)$. Prothrombin time 22 seconds, control 28 seconds. Stools: Color varied from gray to brown, guaiac negative. Ascitic fluid: Histological examination of centrifuged sediment negative for neoplastic cells.

$X$-ray examination of esophagus: No evidence of varices.

Liver biopsy: (This was carried out approximately 6 months following albumin studies when patient was no longer jaundiced, had lost most of his ascites and edema, and had almost doubled his serum albumin level although there had been no change in bromsulfthalein retention.) Grossly the appearance of the liver was red with striking fine granulations. Microscopically the architecture of the liver lobules gave evidence of recent regeneration. Intracellular hyaline material was absent. The portal regions were rich in connective tissue and in regenerating bile capillaries with little acute but some evidence of chronic inflammation.

Pathological diagnosis: Toxic cirrhosis, healed acute yellow atrophy.

H. F. (M-67419), a 63-year-old Italian laborer entered the Peter Bent Brigham Hospital because of jaundice and abdominal swelling.

Long a steady drinker, for 2 years before admission he averaged a quart of wine per day. For many years he had excluded meat from his diet, which was otherwise adequate in distribution and contained milk and an occasional egg. There had been no chemical exposure.

Although for the past 6 or 7 years he had had episodes of light stools and dark urine, he denied previous jaundice, abdominal pain, or vomiting until the onset of afebrile, nonradiating, right upper quadrant cramps which accompanied the intermittent icterus and abdominal swelling in the month before admission.

Physical examination: A deeply icteric man with a strikingly distended abdomen and moderate ankle edema was without respiratory distress. There were no spider angiomata. Liver palms were present. Save for a few râles at the bases, the lungs were clear although the diaphragms were high. The heart was normal. The abdomen was so tensely distended with fluid that no organs could be made out. Superficial abdominal veins were prominent.

Laboratory data: Blood Hinton negative. Urines: Negative beyond bilirubinuria. Blood: Hematocrit 42, sedimentation rate $10 \mathrm{~mm}$. per hour, white cells normal in quantity and distribution. Total protein 6.2 grams per cent, albumin 1.8 grams per cent, globulin 4.4 grams per cent (Howe method). Icterus index 80. Prothrombin time 65 seconds, control 45 seconds. Bromsulfthalein 65 per cent retention in 35 minutes. Stools were yellow to brown in color, guaiac $1+$. Ascitic fluid: Histological examination of centrifuged sediment negative for neoplastic cells.

$X$-ray examinations: Esophagus: No evidence of varices. Flat plate of abdomen: Calcified stones in gall bladder.

Autopsy findings: The liver showed evidence of old portal cirrhosis on which was superimposed biliary cirrhosis as evidenced by acute inflammatory changes in the portal areas, proliferation of bile ducts and bile stasis. The gall bladder was filled with stones and a stone was impacted in the common duct at the ampulla of Vater.

Pathological diagnosis: Laennec's and biliary cirrhosis, cholelithiasis with stone in common duct.

J. B. (M-67135), a 52-year-old white insurance executive was admitted to the Peter Bent Brigham Hospital for intermittent jaundice of 3 years' and abdominal swelling of 3 weeks' duration.

Diet had been adequate in quantity and distribution, there had been no alcoholism or chemical exposure, and no evidence of liver or biliary tract disease until the development of painless afebrile icterus with acholic stools 3 years before admission. At 2 laparotomies performed at this time, evidence of stricture of the right hepatic duct was obtained. Scrapings from the duct were suggestive though not diagnostic of carcinoma. There was no liver biopsy. In the intervening years, closure of a biliary fistula resulted in chronic intermittent jaundice, and although the liver steadily increased in size and function tests indicated increasing impairment, on a high-carbohydrate, low-protein, low-fat diet with supplementary vitamins nutritional status was fairly well maintained until 2 months before admission.

Physical examination: A wasted, deeply jaundiced man with a markedly distended abdomen had moderate ankle edema. There were no spider angiomata. The diaphragms were high bilaterally. The abdominal venous markings were prominent. A sharp hard liver edge was ballotted $15 \mathrm{~cm}$. below the right costal margin in an abdomen distended with fluid. The spleen was not palpable.

Laboratory data: Blood Hinton negative. Urines: 
Negative save for bilirubinuria and slight proteinuria. Blood: Hemoglobin 12.1 grams per cent, hematocrit 37, sedimentation rate $54 \mathrm{~mm}$. in 1 hour, white cells 15,000 per c.mm., differential normal. Total protein 6.4 grams per cent, albumin 2.3 grams per cent, globulin 4.1 grams per cent (Howe method). Icterus index 96. Prothrombin time 195 seconds, control 55 seconds. Cephalin flocculation $3+$ in 24 hours. (Intravenous hippuric acid test gave excretion of only 0.16 grams in 1 hour a year before admission.) Stool guaiacs varied between $1+$ and $3+$, color varied between gray and dark brown.

$X$-ray examination of the esophagus: No evidence of varices.

Autopsy findings: An adenocarcinoma, apparently arising at the bifurcation of the hepatic duct in the liver, had both extensively infiltrated the liver and gall bladder and had given rise to metastases on the peritoneal surfaces and in the peripancreatic nodes. In addition to massive neoplastic infiltration, the liver showed extraordinarily severe biliary cirrhosis with prominent interlobular fibrosis, bile casts in the canaliculi between liver cells, and bile duct proliferation.

Pathological diagnosis: Biliary cirrhosis, abdominal carcinomatosis secondary to carcinoma of bile duct.

The authors are indebted to:

1. Dr. Laurence E. Strong and the Staff of the Plasma Fractionation Laboratory for the preparation of the saltpoor albumin, and to Dr. Geoffrey Edsall and the Staff of the Antitoxin and Vaccine Laboratory of the Massachusetts Department of Public Health for control of sterility and safety.

2. Mr. Metchie J. E. Budka, Mrs. Margaret Y. Clark, and Miss Winifred Prince for carrying out most of the electrophoretic analyses.

3. Dr. John G. Gibson, II, for the determination of plasma volume by the Evans blue method.

4. Mrs. Ruth C. Ferguson, Research Dietitian, and Miss Janet E. Clark, Metabolism Nurse, for their valued assistance.

\section{BIBLIOGRAPHY}

1. Patek, A. J., Jr., and Post, J., Treatment of cirrhosis of the liver by a nutritious diet and supplements rich in vitamin B complex. J. Clin. Invest., 1941, 20, 481.

2. Wiener, H. J., and Wiener, R. E., Plasma proteins. Arch. Int. Med., 1930, 46, 236.

3. Myers, W. K., and Keefer, C. S., Relation of plasma proteins to ascites and edema in cirrhosis of the liver. Arch. Int. Med., 1935, 55, 349.

4. Tumen, H., and Bockus, H. L., The clinical significance of serum proteins in hepatic diseases. Am. J. M. Sc., 1937, 193, 788.

5. Foley, E. F., Keeton, R. W., Kendrick, A. B., and Darling, D., Alterations in serum protein as an index of hepatic failure. Arch. Int. Med., 1937, 60, 64.

6. Snell, A. M., The effects of chronic disease of the liver on the composition and physicochemical properties of blood; changes in the serum proteins; reduction in the oxygen saturation of the arterial blood. Ann. Int. Med., 1935, 9, 690.

7. Post, J., and Patek, A. J., Jr., Serum proteins in relation to liver disorders. Bull. New York Acad. Med., 1943, 19, 815.

8. Loeb, R. F., Atchley, D. W., and Palmer, W. W., On the equilibrium condition between blood serum and serous cavity fluids. J. Gen. Physiol., 1922, 4, 591.

9. Kellermann, V., Das Verhalten des kolloidosmotischen (onkotischen) Druckes im Verlaufe von Lebererkrankungen. Ztschr. f. d. ges. exper. Med., 1937, 100, 337.

10. Butt, H. R., Snell, A. M., and Keys, A., Plasma protein in hepatic disease; a study of the colloid osmotic pressure of blood serum and of ascitic fluid in various diseases of the liver. Arch. Int. Med., 1939, 63, 143.

11. Conn, J. W., Newburgh, L. H., Johnston, M. W., and Sheldon, J. M., Study of the deranged carbohydrate metabolism in chronic infectious hepatitis. Arch. Int. Med., 1938, 62, 765.

12. Greene, C. H., Physiologic considerations in the treatment of portal cirrhosis. J. A. M. A., 1943, 121, 715.

13. Janeway, C. A., Gibson, S. T., Woodruff, L. M., Heyl, J. T., Bailey, O. T., and Newhouser, L. R., Chemical, clinical, and immunological studies on the products of human plasma fractionation. VII. Concentrated human serum albumin. J. Clin. Invest., 1944, 23, 465.

14. Scatchard, G., Strong, L. E., Hughes, W. L., Jr., Ashworth, J. N., and Sparrow, A. H., Chemical, clinical, and immunological studies on the products of human plasma fractionation. XXVI. The properties of solutions of human serum albumin of low salt content. J. Clin. Invest., 1945, 24, 671.

15. Thorn, G. W., Armstrong, S. H., Jr., Davenport, V. D., Woodruff, L. M., and Tyler, F. H., Chemical, clinical, and immunological studies on the products of human plasma fractionation. XXX. The use of salt-poor concentrated human serum albumin solution in the treatment of chronic Bright's disease. J. Clin. Invest., 1945, 24, 802.

16. Gutman, A. B., Moore, D. H., Gutman, E. B., McClellan, V., and Kabat, E. A., Fractionation of serum proteins in hyperproteinemia, with special reference to multiple myeloma. J. Clin. Invest., 1941, 20, 765.

17. Dole, V. P., The electrophoretic patterns of normal plasma. J. Clin. Invest., 1944, 23, 708.

18. Armstrong, S. H., Jr., Budka, M. J. E., Morrison, K. M., and Hasson, M., The refractive index increments and nitrogen factors of normal pooled human plasma proteins and normal human serum albumin. To be published.

19. Howe, P. E., The use of sodium sulfate as the globulin precipitant in the determination of the proteins in blood. J. Biol. Chem., 1921, 49, 93. 
20. Ottenberg, R., and Spiegel, R., The present status of non-obstructive jaundice due to infectious and chemical agents. Causative agents, pathogenesis, inter-relationships, clinical characteristics. Medicine, 1943, 22, 27.

21. Gray, S. J., and Barron, E. S. G., The electrophoretic analyses of the serum proteins in diseases of the liver. J. Clin. Invest., 1943, 22, 191.

22. Hopper, J., Jr., Winkler, A. W., and Elkinton, J. R., Simultaneous measurements of the blood volume in man and dog by/means of Evans blue dye, T1824, and by means of carbon monoxide. II. Under $a b$ normal conditions, including secondary shock. J. Clin. Invest., 1944, 23, 636.

23. Scatchard, G., Batchelder, A. C., and Brown, A., Chemical, clinical, and immunological studies on the products of human plasma fractionation. VI. The osmotic pressure of plasma and of serum albumin. J. Clin. Invest., 1944, 23, 458.

24. Heyl, J. T., Gibson, J. G., 2nd, and Janeway, C. A., Studies on the plasma proteins. V. The effect of concentrated solutions of human and bovine serum albumin on blood volume after acute blood loss in man. J. Clin. Invest., 1943, 22, 763.

25. Armstrong, S. H., Jr., Budka, M. J. E., and Morrison,
K. M., Preparation and properties of serum and plasma proteins. V. The analysis of the electrophoretic schlieren diagram and the estimation of the albumin content of normal pooled human plasma. J. Am. Chem. Soc., In press.

26. Ralli, E. P., Robson, J. S., Clarke, D., and Hoagland, C. L., Factors influencing ascites in patients with cirrhosis of the liver. J. Clin. Invest., 1945, 24, 316.

27. Eaton, M. D., Murphy, W. D., and Hanford, V. L., Heterogenetic antibodies in acute hepatitis. J. Exper. Med., 1944, 79, 539.

28. Kass, E. H., The occurrence of normal serum gammaglobulin in human lymphocytes. Science, 1945, 101, 337.

29. Cohn, E. J., Oncley, J. L., Strong, L. E., Hughes, W. L., Jr., and Armstrong, S. H., Jr, Chemical, clinical, and immunological studies on the products of human plasma fractionation I. The characterization of the protein fractions of human plasma. J. Clin. Invest., 1944, 23, 417.

30. Gibson, S. T., Personal communication.

31. Weech, A. A., and Goettsch, E., Dietary protein and the regeneration of serum albumin. I. Method of assay and discussion of principles. Bull. Johns Hopkins Hosp., 1938, 63, 154. 